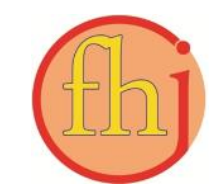

Faletehan Health Journal, 8 (1) (2021) 31-55

www. journal.Ippm-stikesfa.ac.id/ojs/index.php/FHJ

ISSN 2088-673X | e-ISSN 2597-8667

\title{
Hubungan antara Grade Hipertensi dengan Tingkat Kemandirian Lansia dalam Activities Of Daily Living (ADLs)
}

\author{
Irma Darmawati ${ }^{1 *}$, Febri Andri Kurniawan ${ }^{2}$ \\ ${ }^{1}$ Prodi Keperawatan, Fakultas Pendidikan Olahraga dan Kesehatan, Universitas Pendidikan Indonesia \\ ${ }^{2}$ Puskesmas Panca, Dinas Kesehatan Kabupaten Bandung \\ *Corresponding Author: irmadarmawati@upi.edu
}

\begin{abstract}
Abstrak
Prevalensi hipertensi di Indonesia semakin meningkat setiap tahun terutama pada kelompok lansia. Penurunan tingkat kemandirian lansia akibat hipertensi menjadi perhatian utama dalam rangka pencapaian kualitas hidup yang optimal. Tujuan penelitian ini adalah untuk mengetahui hubungan antara derajat hipertensi pada lansia dengan tingkat kemandirian dalam menjalankan aktivitas sehari-hari. Pengambilan sampel dilakukan secara cluster sampling berjumlah 49 lansia hipertensi. Penelitian ini menggunakan pendekatan kuantitatif dengan desain cross sectional. Analisa hubungan variabel grade hipertensi dan tingkat kemandirian menggunakan analisis korelasi spearman rank. Hasil penelitian menunjukan 55,1\% lansia mengalami hipertensi grade II dan 49\% lansia mengalami ketergantungan sebagian. Berdasarkan analisa korelasi spearman rank di dapatkan hasil $p$ value $0,000(<0,05)$ dan $r-0,56$ dengan kesimpulan terdapat hubungan yang cukup kuat antara penyakit hipertensi dengan kemandirian lansia, dengan arah hubungan yang negatif artinya semakin tinggi tekanan darah maka semakin rendah kemandirian lansia. Perubahan tingkat kemandirian lansia yang diakibatkan oleh hipertensi ini seyogyanya menjadi perhatian perawat agar selalu melakukan monitoring grade hipertensi pada lansia secara rutin setiap bulan. Keterlibatan keluarga ditingkatkan untuk memberikan dukungan keluarga yang dapat membantu lansia agar kualitas hidup lansia hipertensi tetap dapat tercapai secara optimal.
\end{abstract}

Kata Kunci: Derajat Hipertensi, Lansia, Tingkat kemandirian

\section{Relationship between Grade of Hypertension and Elderly Independence in Activities of Daily Living (ADLs)}

\begin{abstract}
The prevalence of hypertension in Indonesia has continued to increase. Decreasing the level of elderly independence due to hypertension is a major concern in achieving optimal quality of life. The purpose of this study was to determine the relationship between hypertension grade and independence level in activities of daily living. There were 49 participants selected by cluster sampling from elderly who diagnosed with hypertension. This research used a quantitative approach with cross sectional design. Analysis of the relationship between hypertension grade and elderly independence using Spearman rank correlation. The results showed that $55.1 \%$ of the elderly had grade II hypertension and $49 \%$ of the elderly had partial dependence. Based on correlation analysis, the results obtained $p$ value $0.00(<0.05)$ and $r-0.56$ with the conclusion that there is a fairly strong relationship between hypertension and independence of the elderly, with a negative direction means the higher blood pressure give a lower the elderly independence. Changes in the level of elderly independence caused by hypertension should be a concern for nurses to always monitor the grade of hypertension regularly every month. Family involvement is enhanced to provide family support that can help the elderly so that the quality of life of elderly hypertension can still be optimally achieved.
\end{abstract}

Keywords: Hypertension Grades, Elderly, Independence 


\section{Pendahuluan}

Lanjut usia merupakan fase dimana terjadi perpindahan dari dewasa akhir menuju masa usia lanjut yang sering disebut proses penuaan (Rodrigues et al., 2017). Pada tahap dewasa tubuh mencapai tahap perkembangan yang maksimal, selain itu tubuh mulai menyusut dikarenakan berkurangnya jumlah sel-sel yang ada di dalam tubuh, sebagai akibatnya tubuh juga akan mengalami penurunan fungsi secara perlahanlahan (Setters \& Holmes, 2017). Penuaan atau proses terjadinya tua adalah suatu proses menghilangnya secara perlahan-lahan kemampuan jaringan untuk memperbaiki diri atau mengganti dan mempertahankan fungsi normalnya sehingga tidak dapat bertahan terhadap infeksi serta memperbaiki kerusakan yang diderita (Benetos, Petrovic, \& Strandberg, 2019).

Studi epidemiologis dan klinis menemukan bahwa proses penuaan berhubungan dengan penurunan kinerja kognitif dan juga tingkat kemandirian pada lansia (Darmawati, Purnama, \& Lindayani, 2019). Kemandirian bagi orang lanjut usia dapat dilihat dari kemampuan melakukan activities of daily living (ADL) yang dapat diukur melalui Barthel Index (Ohura, Hase, Nakajima, \& Nakayama, 2017). Secara umum, semakin menua seseorang, kondisi kesehatan juga akan mengalami penurunan, itu disebabkan oleh menurunnya fungsi-fungsi organ dalam tubuh, penurunan fungsi tersebut dialami lansia secara alamiah ataupun disebabkan oleh pengaruh penyakit (Setters \& Holmes, 2017).

Prevalensi penyakit yang sering diderita lansia adalah hipertensi, penyakit radang sendi, penyakit paru obstruktif kronis, kanker, dan diabetes melitus. Prevalensi hipertensi pada lansia mencapai angka $63,2 \%$ pada kelompok umur 65-74 tahun dan $69.5 \%$ pada kelompok umur $>75$ tahun (Kemenkes, 2018). Data tersebut dapat menunjukan bahwa salah satu penyakit yang sangat erat kaitannya dengan lansia adalah hipertensi. Hipertensi menempati penyakit nomor satu yang sering terjadi pada lansia. Menurut ESC (European Society of Cardiology), penderita tekanan darah tinggi dapat ditemukan satu dari setiap tiga orang (Lee et al., 2018).

Berdasarkan data Puskesmas Pacet, lanjut usia yang tercatat aktif pada program kesehatan lansia adalah sebesar 106 orang dan sekitar 44,8\% lansia mengalami hipertensi dan menempati urutan pertama masalah kesehatan. Hipertensi adalah suatu keadaan di mana seseorang mengalami peningkatan tekanan diatas normal yang ditunjukan oleh angka systolic dan angka diastolic pada pemeriksaan tensi darah menggunakan alat pengukur tekanan darah baik yang berupa cuff air raksa ataupun alat digital lainnya. Penyakit ini dikategorikan sebagai the silent disease karena penderita tidak mengetahui dirinya mengidap hipertensi sebelum memeriksakan tekanan darahnya, padahal bila terjadi hipertensi terus menerus bisa memicu penyakit komplikasi lain seperti stoke, serangan jantung dan lain sebagainya (Shadine, 2010).

Kondisi hipertensi pada lansia akan berpengaruh terhadap kemampuan kemandirian lansia. Kondisi kemandirian lansia yang menderita hipertensi dapat menentukan upaya asuhan keperawatan yang akan diberikan. Dengan mengetahui kondisi lansia yang mengalami hipertensi, maka perawat dapat memberikan perlakuan sesuai dengan masalah yang menyebabkan orang lanjut usia tergantung pada orang lain. Kemandirian didefinisikan sebagai kemampuan individu untuk memenuhi kebutuhan hidup dengan tidak bergantung pada orang lain. Selain itu kemandirian diartikan sebagai suatu keadaan dimana seseorang berupaya untuk memenuhi segala tuntutan (Hong et al., 2018).

Lansia yang mandiri adalah lansia yang kondisinya sehat dalam arti luas masih mampu untuk menjalankan kehidupan pribadinya. Kemadirian pada lansia meliputi kemampuan lansia dalam melakukan aktifitas sehari-hari ,seperti : mandi, berpakaian rapi, pergi ke toilet, berpindah tempat, dapat mengontrol BAK, atau $\mathrm{BAB}$, serta dapat makan sendiri (Ohura et al., 2017). Penelitian pada 8.648 lansia di Shanghai memperlihatkan bahwa ketidakmampuan lansia hipertensi untuk mandiri dalam melaksanaan ADL adalah sebesar 32,47\% (Su et al., 2020). Namun penelitian tersebut belum secara jelas menggambarkan derajat hipertensi yang mempengaruhi tingkat kemandirian pada lansia. Tujuan penelitian ini untuk mengetahui hubungan tingkat kemandirian lansia didasarkan pada perbedaan grade hipertensi yang diderita oleh lansia. 
Faletehan Health Journal, 8 (1) (2021) 31-35

\section{Metodologi Penelitian}

Penelitian ini adalan penelitian kuantitatif dengan pendekatan cross sectional melalui studi korelasional untuk mengetahui hubungan derajat hipertensi dengan kemandirian lansia di wilayah kerja puskesmas pacet. Teknik sampling yang digunakan dalam penelitian ini yaitu dengan menggunakan cluster sampling yaitu dengan cara mengelompokkan atau dengan gugusan yang dalam penelitian ini dibuat secara gugus bertahap yaitu gugus terdekat dengan puskesmas, gugus pertengahan, dan gugus terjauh dari puskesmas dari sejumlah populasi 106 lansia berusia $>60$ tahun. Sampel yang didapatkan dalam penelitian ini adalah 49 orang yang didapatkan secara cluster sampling dari RW Mekarsari, RW Pasirpari dan RW Panggilingan. Penelitian ini telah melalui uji etik dengan izin nomor II/011/KEPK/STIKep/PPNI/Jabar/2019.

Instrumen pengumpulan data yang digunakan pada penelitian ini adalah alat sphigmomanometer untuk mengukur tekanan darah pada lansia dengan berpedoman pada grade hipertensi oleh European Society of Cardiology (Bergler-Klein, 2019) serta instrumen Bathel Index untuk mengukur kemandirian lansia. Kemandirian lansia dikategorikan menjadi 3 kategori yakni mandiri, ketergantungan sebagian, dan ketergantungan total oleh perawat. Analisa data yang digunakan adalah Korelasi Spearman (Spearman Rank Order Correlation) untuk menganalisis hubungan antara grade hipertensi yang diderita dengan tingkat kemandirian pada lansia.

\section{Hasil dan Pembahasan}

Karakteristik responden yang terlibat dalam penelitian ini dijelaskan dalam tabel 1. Sebanyak 49 pasien hipertensi berpartisipasi dalam penelitian ini. Dari 49 responden, 55,1\% lansia mengalami hipertensi grade 2 sesuai kategori European Society of Cardiology tahun 2018 dengan rentang tekanan darah sistolik 160-179 $\mathrm{mm} \mathrm{Hg}$ dan diastolik 100-109 mm Hg (Bergler-Klein, 2019). Dalam tabel ini juga dijelaskan bahwa tingkat kemandirian pada lansia hipertensi menunjukan memiliki ketergantungan sebagian (49\%).

Kesehatan fisiologis dapat mempengaruhi kemampuan partisipasi dalam activities of daily living (ADL), kondisi sakit serta trauma injuri dapat mengganggu pemenuhan ADL. ADL merupakan suatu bentuk pengukuran kemampuan seseorang untuk melakukan aktifitas kehidupan sehari-hari secara mandiri. Penentuan kemandirian fungsional dapat mengidentifikasi kemampuan dan keterbatasan klien sehingga memudahkan pemilihan intervensi yang tepat (Maryam, 2012). Lanjut usia yang memiliki tingkat kemandirian tertinggi adalah mereka yang secara fisik dan psikologis memiliki kesehatan yang cukup prima. Presentase yang paling tinggi adalah mereka yang mempunyai kesehatan baik. Status kesehatan yang baik akan berdampak pada kemampuan melakukan aktivitas apa saja dalam kehidupan sehari-hari seperti: mengurus diri sendiri, bekerja dan rekreasi. Pada penelitian ini didapatkan hal yang sesuai bahwa tingkat keparahan penyakit sebanding dengan tingkat kemandiriannya. Hal ini pun sejalan dengan pendapat hasil penelitian Jumita, Azrimaidaliza, \& Machmud (2012) bahwa lansia yang memiliki kesehatan baik memiliki kemandirian yang baik dengan presentase sebesar $97,4 \%$.

Tabel 1. Distribusi Frekuensi Responden ( $\mathrm{n}=49$ )

\begin{tabular}{lcc}
\hline \multicolumn{1}{c}{ Grade Hipertensi } & n & \% \\
\hline Grade 1 & 13 & 26,5 \\
SBP : $140-149 \mathrm{~mm} \mathrm{Hg}$ & & \\
DBP : $90-99 \mathrm{~mm} \mathrm{Hg}$ & & \\
\hline Grade 2 & 27 & 55,1 \\
SBP $: 160-179 \mathrm{~mm} \mathrm{Hg}$ & & \\
DBP : $100-109 \mathrm{~mm} \mathrm{Hg}$ & & \\
\hline Grade 3 & 9 & 18,4 \\
SBP $>180 \mathrm{~mm} \mathrm{Hg}$ & & \\
DBP $>110 \mathrm{~mm} \mathrm{Hg}$ & & \\
\hline
\end{tabular}

Sumber: Data Primer, 2019

Tabel 2. Distribusi Frekuensi Responden ( $\mathrm{n}=49$ )

\begin{tabular}{lcc}
\hline \multicolumn{1}{c}{ Tingkat Kemandirian } & n & \% \\
\hline Mandiri & 19 & 38,8 \\
\hline Ketergantungan sebagian & 24 & 49 \\
\hline Ketergantungan total & 6 & 12,2 \\
\hline
\end{tabular}

Sumber: Data Primer, 2019

Penelitian ini menunjukkan bahwa seluruh lansia memiliki tekanan darah tinggi dengan prevalensi tertinggi pada grade dua dan juga mengalami tingkat ketergantungan sebagian pada 49\% lansia. Beberapa faktor yang dapat mempengaruhi kemandirian pada lansia yaitu kesehatan fisiologis, tingkat stress, status mental dll (Caskie, Sutton, \& Margrett, 2010). Secara umum kondisi fisiologis seseorang yang telah memasuki masa lanjut usia mengalami penurunan hal ini disebabkan karena hilangnya kemampuan 
jaringan untuk memperbaiki dirinya atau mempertahankan dirinya (Abdi, Hariyanto, \& Ardiyani, 2017). Adanya proses penuaan ditambah dengan kondisi penyakit hipertensi ini mengakibatkan gangguan yang cukup besar sampai berkurangnya kemampuan memenuhi aktifitas sehari-hari dan seringkali membutuhkan bantuan keluarga dalam mencukupi kebutuhan hidupnya (Darmawati \& Dulgani, 2019).

Berdasarkan Tabel 3 dapat dilihat bahwa lansia dengan hipertensi grade 1 memiliki tingkat kemandirian mandiri dan ketergantungan sebagian, tanpa ada satu pun yang mengalami ketergantungan total. Hipertensi grade 2 menggambarkan adanya seluruh tingkat ketergantungan baik mandiri, sebagian dan total. Sebaliknya dengan lansia yang memiliki hipertensi grade 3 memiliki tingkat kemandirian total dan sebagian tanpa ada yang mampu mandiri dalam pelaksanaan activities of daily living. Berdasarkan tabel diatas juga menunjukan bahwa p value $0,00<$ $\alpha(0,05)$ dengan koefisien korelasi $-0,56$, sehingga demikian hipotesa nol ditolak yang berarti terdapat hubungan yang cukup kuat antara penyakit hipertensi dengan kemandirian lansia, Arah dari hubungan ini bernilai negatif yang artinya semakin tinggi tekanan darah maka semakin rendah tingkat kemandirian lansia.

Gangguan dalam pemenuhan aktivitas sehari hari bermakna berkurangnya tingkat kemandirian lansia dalam beraktifitas. aktifitas yang dimaksud diantaranya kemampuan untuk makan, minum, berpindah tempat, personal hygiene, berjalan dan naik tangga, kontrol BAK/BAB, serta olahraga dan rekreasi (Ohura et al., 2017). ADL ini dilakukan secara berulang setiap hari. Dalam penelitian ini ditemukan bahwa hampir setengah responden memiliki ketergantungan sebagian pada beberapa aktifitas harian dan harus bergantung pada keluarga terdekatnya. Penurunan kemampuan beraktifitas sehari-hari ini diakibatkan perubahan menua pada lansia dan juga manifestasi klinis penyakit hipertensi yang mengakibatkan responden harus meminta bantuan kepada anggota keluarganya dalam memenuhi kebutuhannya sehari-hari (Abdi et al., 2017).

Penelitian ini menemukan hasil bahwa semakin tinggi grade hipertensi maka akan semakin tinggi tingkat ketergantungan lansia terhadap care giver nya yang dalam hal ini adalah keluarga pada tatanan komunitas. Semakin tinggi grade hipertensi maka seringkali terjadi disfungsi sistem saraf pusat, sakit kepala daerah oksipital, pusing, vertigo, dan penglihatan kabur. Hal ini yang mengakibatkan lansia mengalami kesulitan dalam melakukan aktifitas sehari-hari (Caskie et al., 2010).

Pemenuhan ADL pada lansia membutuhkan peranan penting dari keluarga sebagai caregiver. Keluarga memegang peranan penting dalam menentukan prioritas dan pencapaian tujuan optimalisasi kesehatan pada lansia (Mosca et al., 2012). Keluarga memiliki peranan dalam upaya pemenuhan setiap ADL lansia serta upaya optimalisasi kebutuhan dasar manusia pada lansia dengan hipertensi. Optimalisasi peran ini membutuhkan perhatian dari perawat dalam perencanaan asuhan keperawatan pada lansia hipertensi untuk mengoptimalkan peran keluarga dalam pemberian asuhan. Peran perawat dalam kasus lansia hipertensi dengan penurunan tingkat kemandirian ini difokuskan pada pemberian dukungan baik bagi lansia maupun keluarga untuk dapat mempertahankan kondisi kesehatan yang ada, dan tetap memberikan kesempatan pada lansia untuk melakukan aktifitas kehidupan sehari hari seoptimal mungkin dan diberikan bantuan saat lansia tersebut membutuhkan. Pelaksanaan ADL sebaiknya tetap distimulasi agar lansia tetap mampu memenuhi kebutuhan aktifitas fisiknya yang akan memberikan dampak positif terhadap kondisi kesehatan lansia dengan pendampingan oleh keluarga dan perawat.

Tabel 3. Grade Hipertensi dengan Tingkat Kemandirian Lansia $(\mathrm{n}=49)$

\begin{tabular}{|c|c|c|c|c|c|}
\hline \multirow[b]{2}{*}{ Grade } & \multicolumn{3}{|c|}{ Tingkat Kemandirian } & \multirow[b]{2}{*}{$\begin{array}{c}\mathbf{P} \\
\text { value }\end{array}$} & \multirow[b]{2}{*}{$\mathbf{r}$} \\
\hline & Mandiri & $\begin{array}{c}\text { Ketergantungan } \\
\text { Sebagian }\end{array}$ & $\begin{array}{c}\text { Ketergantungan } \\
\text { Total }\end{array}$ & & \\
\hline Grade 1 & 10 & 3 & 0 & \multirow{3}{*}{0,000} & \multirow{3}{*}{$-0,56$} \\
\hline Grade 2 & 9 & 15 & 3 & & \\
\hline Grade 3 & 0 & 6 & 3 & & \\
\hline
\end{tabular}


Faletehan Health Journal, 8 (1) (2021) 31-35 www. journal.Ippm-stikesfa.ac.id/ojs/index.php/FHJ ISSN 2088-673X | 2597-8667

\section{Simpulan}

Berdasarkan hasil penelitian ini maka dapat disimpulkan bahwa perbedaan grade hipertensi pada lansia menunjukan perbedaan tingkat kemandirian pada lansia. Semakin tinggi grade hipertensi bermanifestasi pada rendahnya tingkat kemandirian lansia. Pendampingan keluarga dan perawat pada tatanan primer dibutuhkan untuk optimalisasi pemenuhan activities daily living pada lansia dengan hipertensi.

\section{Referensi}

Abdi, A., Hariyanto, T., \& Ardiyani, V. M. (2017). Aktivitas lansia berhubungan dengan status kesehatan lansia di posyandu permadi kelurahan tlogomas kecamatan lowokwaru kota malang. Nursing News: Jurnal Ilmiah Keperawatan, 2(3).

Benetos, A., Petrovic, M., \& Strandberg, T. (2019). Hypertension management in older and frail older patients. Circulation Research, 124(7), 1045-1060.

Bergler-Klein, J. (2019). What's new in the ESC 2018 guidelines for arterial hypertension. Wiener Klinische Wochenschrift, 131(7-8), 180-185.

Caskie, G. I. L., Sutton, M. C., \& Margrett, J. A. (2010). The relation of hypertension to changes in ADL/IADL limitations of Mexican American older adults. Journals of Gerontology Series B: Psychological Sciences and Social Sciences, 65(3), 296305.

Darmawati, I., \& Dulgani, D. (2019). Perawatan Diri Lansia Hipertensi Di Kelurahan Cirejag Karawang. Jurnal Keperawatan Komprehensif (Comprehensive Nursing Journal), 5(1), 1-9.

Darmawati, I., Purnama, H., \& Lindayani, L. (2019). Skrining Cognitive Impairment Pada Pasien Hipertensi Di Bandung: Screening Cognitive Impairment in Hypertensive Patients in Bandung. Jurnal Ilmiah Keperawatan (Scientific Journal of Nursing), 5(2), 114-120.

Hong, I., Woo, H.-S., Shim, S., Li, C.-Y., Yoonjeong, L., \& Velozo, C. A. (2018). Equating activities of daily living outcome measures: the Functional Independence
Measure and the Korean version of Modified Barthel Index. Disability and Rehabilitation, 40(2), 217-224.

Jumita, R., Azrimaidaliza, A., \& Machmud, R. (2012). Kemandirian Lansia Diwilayah Kerja Puskesmas Lampasi Kota Payakumbuh. Jurnal Kesehatan Masyarakat Andalas, 6(2), 86-94.

Kemenkes, R. I. (2018). Laporan Nasional Riskesdas 2018. Jakarta: Kemenkes RI, 154166.

Lee, J. H., Kim, S.-H., Kang, S.-H., Cho, J. H., Cho, Y., Oh, I.-Y., ... others. (2018). Blood pressure control and cardiovascular outcomes: real-world implications of the 2017 ACC/AHA hypertension guideline. Scientific Reports, 8(1), 1-8.

Mosca, L., Aggarwal, B., Mochari-Greenberger, H., Liao, M., Blair, J., Cheng, B., ... Umann, T. (2012). Association between having a caregiver and clinical outcomes 1 year after hospitalization for cardiovascular disease. American Journal of Cardiology. https://doi.org/10.1016/j.amjcard.2011.07.07 2

Ohura, T., Hase, K., Nakajima, Y., \& Nakayama, T. (2017). Validity and reliability of a performance evaluation tool based on the modified Barthel Index for stroke patients. BMC Medical Research Methodology, 17(1), 131.

Rodrigues, G. P., Cozzolino, S. M. F., do Nascimento Marreiro, D., Caldas, D. R. C., da Silva, K. G., de Sousa Almondes, K. G., ... do Nascimento Nogueira, N. (2017). Mineral status and superoxide dismutase enzyme activity in Alzheimer's disease. Journal of Trace Elements in Medicine and Biology, 44, 83-87.

https://doi.org/https://doi.org/10.1016/j.jtem b.2017.06.005

Setters, B., \& Holmes, H. M. (2017). Hypertension in the older adult. Primary Care: Clinics in Office Practice, 44(3), 529-539.

Su, P., Yang, S., Dong, Z., Liang, W., Zhang, Y., Mei, J., ... Wen, Q. (2020). Interactive Effect of Hypertension and Obesity on Disability among Older People: A Observational Study. 